\title{
Nitrate accumulation at depth and its regolith property controls in a wet subtropical Critical Zone
}

\author{
HUAYONG WU ${ }^{1}$, GANLIN ZHANG ${ }^{12}$ \\ ${ }^{1}$ State Key Laboratory of Soil and Sustainable Agriculture, \\ Institute of Soil Science, Chinese Academy of Sciences, \\ Nanjing 210008, China. hywu@issas.ac.cn \\ ${ }^{2}$ University of Chinese Academy of Sciences, Beijing \\ 100049, China. Corresponding author: \\ glzhang@issas.ac.cn
}

Nitrate accumulation at depth has often been reported in temperate permanent charge soils, but seldomly in tropical and subtropical variable charge soils. The mechanisms on the nitrate accumulation in relation to regolith (soil and saprolite) properties are poorly understood. In this work, four upland regoliths were selected in a typical red soil Critical Zone of wet subtropical China. These regoliths with a thickness of 6 $\mathrm{m}$ to $8 \mathrm{~m}$, which developed from Quaternary red clay underlain by sandstone bedrock, were acidic, highly weathered, and clay loam to clay in texture. On average $92 \%$ $\left(827 \pm 97 \mathrm{~kg} \mathrm{~N} \mathrm{ha}^{-1}\right)$ of $\mathrm{NO}_{3}^{-}-\mathrm{N}$ were found to be stored at depth (from a depth of $1 \mathrm{~m}$ to the bedrock surface) in the upland regoliths. The $\mathrm{NO}_{3}-\mathrm{N}$ mainly accumulated with depth in the upland regoliths from the 1- to 4-m depth interval, while the inventory in the $3-\mathrm{m}$ zone accounted for on average $71 \%$ of the total. Regolith $\mathrm{pH}$ was negatively related to nitrate concentrations, whereas crystalline $\mathrm{Fe}$ and $\mathrm{Al}$ and anion exchange capacity were positively related to nitrate concentrations below both $0 \mathrm{~m}$ and $1 \mathrm{~m}$ depth. Bulk density was significantly correlated with nitrate concentrations below $0 \mathrm{~m}$, while clay, depth, amorphous $\mathrm{Al}$, amorphous $\mathrm{Fe}$, total organic carbon, and total nitrogen were significantly correlated with nitrate concentrations below $1 \mathrm{~m}$. There was no significant relationship between nitrate concentrations and silicate bound $\mathrm{Fe}$, silicate bound $\mathrm{Al}$, sand, silt, $\mathrm{C} / \mathrm{N}$, or moisture below both $0 \mathrm{~m}$ and $1 \mathrm{~m}$. The random forest analysis showed that the relative contributions of $\mathrm{pH}$, crystalline $\mathrm{Fe}$ content, depth, anion exchange capacity, bulk density and crystalline $\mathrm{Al}$ content to interpreting nitrate concentration variations were $28.3 \%, 9.5 \%, 4.3 \%, 3.4 \%, 2.9 \%$ and $2.8 \%$, respectively. Nitrate accumulation at depth in the variable charge soils was most likely determined both by electrostatic adsorption on crystalline $\mathrm{Fe}$ and $\mathrm{Al}$ oxides and low permeability of the regolith at depth, which appeared to be greatly impacted by $\mathrm{pH}$ and competitive anions. 